\title{
Sesquiterpenoid Compounds from The Stembark of Aglaia minahassae (Meliaceae)
}

\section{Nunung Kurniasih ${ }^{1,2}$, Hersa Milawati ${ }^{1}$, Mohamad Fajar ${ }^{1}$, Ace Tatang Hidayat ${ }^{1,2}$, Rizky Abdullah ${ }^{3}$ Desi Harneti ${ }^{1}$, Unang Supratman ${ }^{1,4 *}$, Mohamad Nurul Azmi B Mohamad Taib ${ }^{5}$}

\author{
${ }^{1}$ Department of Chemistry, Faculty of Mathematics and Natural Sciences, \\ Universitas Padjadjaran, Jatinangor, Indonesia \\ ${ }^{2}$ Department of Chemistry, Faculty of Sciences and Technology, Sunan Gunung Djati Islamic State \\ University, Bandung, Indonesia \\ ${ }^{3}$ Department of Pharmacology and Clinical Pharmacy, Faculty of Pharmacy, \\ Universitas Padjadjaran, Jatinangor, Indonesia \\ ${ }^{4}$ Central Laboratory of Universitas Padjadjaran, Jatinangor, Indonesia \\ ${ }^{5}$ School of Chemical Sciences, Universiti Sains Malaysia, Penang, Malaysia \\ *email: unang.supratman@unpad.ac.id
}

Received December 15, 2017; Accepted March 21, 2018; Available online May 31, 2018

\begin{abstract}
Two sesquiterpenoid compounds, 4(15)-eudesmen-1 $\beta, 6 \alpha$-diol (1) and spathulenol (2) have been isolated from the stembark of Aglaia minahassae belong to Meliaceae family. The chemical structures of $\mathbf{1}$ and $\mathbf{2}$ were identified on the basis of spectroscopic evidence including UV, IR, NMR 1D, NMR 2D as well as mass spectra and by comparison with those previously reported spectra data. This compounds were isolated from this plant for the first time.
\end{abstract}

Key words: Sesquiterpenoid, Aglaia minahassae, 4(15)-eudesmen-1 $\beta, 6 \alpha$-diol, spathulenol.

\section{INTRODUCTION}

Meliaceae plant is the important plant families that have utilization and generally grow in the tropical countries. Meliaceae plant are known for the presence of the various secondary metabolite compounds that exhibit interesting biological activity such as hypoglycemia, anticancer, anti-inflammation, antifeedant, antitumor (Awang et al., 2012; Leong et al., 2016; Su et al., 2006) and insecticidal activity (Nugroho et al., 1999).

The Aglaia genus is a plant of the tropical rain forest in the Indomalesiana region and mainly distributed in tropical countries including India, Indonesia, Malaysia and parts of the Western Pacific. Aglaia is the largest genus belong to Meliaceae family contain more than 150 species (Hidayat et al., 2017a; Hidayat et al., 2017b; Awang et al., 2012) and about 65 species grown in Indonesia (Wood et al., 1970; Heyne 1982). Aglaia species are mainly distributed in the tropical rainforest of Southeast Asia and on the Pacific islands (Leong et al., 2016; Hidayat et al., 2017b). Phytochemical studies on Aglaia species have led to the identification of main compounds such as sesquiterpenoids (Joycharat et al., 2010; Liu et al., 2014; Pan et al., 2014), diterpenoids (Cai et al.,, 2010; Yodsaoue et al., 2012), rocaglate derivatives (Nugroho et al.,
1999; Farabi et al., 2017; Hidayat et al., 2017a), lignans (Sianturi et al., 2016), dammarane-type triterpenoids (Xie, et al., 2007; Zhang, et al., 2010; Harneti et al., 2012; Farabi et al., 2017), cycloartane-type triterpenoids (Awang et al., 2012) and steroids (Harneti et al., 2014; Zhang et al., 2016).

Sesquiterpenes are less volatile than terpenes, have a greater potential for stereochemical diversity and stronger odors (Waterman, 1993). They are anti-inflammatory (Jeena et al., 2013) and have bactericidal properties (Ishnava et al., 2013). Sesquiterpenes oxidize over time into sesquiterpenols. In patchouli oil, this oxidation is thought to improve the odor. One of the most anti-inflammatory sesquiterpenes, chamazulene, only has 14 carbon atoms but is usually included with sesquiterpenes. Chamazulene and caryophyllene have strong antioxidant (Ornano et al., 2013) and antitumor activity (Feraz et al., 2013; Park, et al., 2011). Some sesquiterpenes such as $\alpha$-farnesene can be effective against the bacteria that cause tooth decay (Ishnava et al 2013).

Liu et al. (2014) isolated and discribed four guaian sesquiterpenes and an eudesmene sesquiterpene from the twigs of Aglaia odorata var. microphyllina. Pan et al. (2010) were isolated eudesmene-type sesquiterpene from the stem bark of Aglaia foveolata obtained in 
Kalimantan, Indonesia. Although sesquiterpenoids of other Aglaia species have been investigated previously, the sesquiterpenoid derivatives of $A$. minahassae is yet to be reported. In this communication, the isolation and structure identification of eudesmene-type and aromadendran-type sesquiterpenoids are described.

\section{EXPERIMENTAL SECTION}

\section{General Experiment Procedure}

The IR spectra were recorded on a PerkinElmer spectrum-100 FT-IR (Waltwam, MA, USA) in $\mathrm{KBr}$. Mass spectra were obtained with a Synapt G2 mass spectrometer instrument (Waters, Milford, MA, USA). NMR spectral data were performed on a Bruker Topspin spectrometer at $500 \mathrm{MHz}$ (Bruker BioSpin $\mathrm{GmbH}$, Silberstreifen 4, D-76287 Rheinstetten, Germany), with $\mathrm{CDCl}_{3}$ as a solvent, chemical shifts were given on a $\delta(\mathrm{ppm})$ scale and tetramethylsilane (TMS) as an internal standard. Column chromatography was conducted on silica gel 60 (Merck, Darmstadt, Germany) and octadesyl sylane (ODS, Fuji Sylisia, Japan). TLC plates were precoated with silica gel $\mathrm{GF}_{254}$ (Merck, $0.25 \mathrm{~mm}$ ) and detection was achieved by spraying with $10 \%$ $\mathrm{H}_{2} \mathrm{SO}_{4}$ in $\mathrm{EtOH}$, followed by heating.

\section{Plant Material}

The stembark of A. minahassae were collected in Bogor Botanical Garden, Bogor, West Java Province, Indonesia in January 2016. The plant was identified by the staff of the Bogoriense Herbarium, Research Center for Biology, Indonesian Institute of Science, Bogor, Indonesia and a voucher specimen (No. BO-1294551) has been deposited at the herbarium.

\section{Extraction and Isolation}

The dried stembark of A. minahassae $(1.68 \mathrm{~kg})$ was extracted with methanol $(12 \mathrm{~L})$ at room temperature for 3 days. The methanol extract was evaporated under vacuum to yield a dark brown residue $(225.1 \mathrm{~g})$. This residue was dissoved in water and partioned succesively with $n$-hexane $(10 \mathrm{~L})$, ethyl acetate $(10 \mathrm{~L})$ and $n$-butanol $(10 \mathrm{~L})$. Evaporated of this extracts resulted of $n$-hexane $(9.38 \mathrm{~g})$, ethyl acetate (7.05 g) and $n$-butanol (7.63 g), respectively.

The $n$-hexane extract $(9.38 \mathrm{~g})$ was separated by vacuum liquid chromatography
(VLC) on silica gel G60 using a gradient elution of $n$-hexane-ethyl acetate (10:0 to $0: 10)$ then ethyl acetate-methanol (10:0 to $0: 10)$ to give eight fractions $(\mathrm{A}-\mathrm{H})$. The $\mathrm{D}$ fraction $(2.85 \mathrm{~g})$ was separated by column chromatography on silica gel using a gradient elution of $n$-hexane-ethyl acetate (10:0 to 4:6) to yield twelve fractions (D1-D12). Furthermore, the D7 fraction $(217.3 \mathrm{mg})$ was separated by column chromatography on silica gel eluted with methylene chloride: acetone (19: 1) to give five fractions (D7.1-D7.5). The D7.2 fraction $(82.0 \mathrm{mg})$ was separated by column chromatography on octadesyl silane (ODS) eluted with methanol: acetonitrile: water (11: 2: 7) to yield compound 1 (21.5 $\mathrm{mg})$.

The $\mathrm{C}$ fraction (1.75 $\mathrm{g}$ ) was separated by column chromatography on silica gel using a gradient elution of $n$-hexane-ethyl acetate (10:0 to $0: 10)$ to obtained nine fractions (C1C9). Subsequently, the $\mathrm{C} 7$ fraction $(267.3 \mathrm{mg}$ ) was separated by column chromatography on silica gel eluted with $n$-hexane : chloroform : acetone (95: 5: 5) to obtained six fractions (C7.1-C7.6). The C7.3 fraction (42 mg) was separated by preparative TLC on silica gel $\mathrm{GF}_{254}$ eluted with $n$-hexane: toluene: acetone (15: 4: 1) to obtained compound $2(4.0 \mathrm{mg})$.

\section{RESULTS AND DISCUSSION}

The $n$-hexane extract of the stembark of $A$. minahassae was chromatographed over a vacuum-liquid chromatographed (VLC) column packed with silica gel 60 by gradient elution. The VLC fractions were repeatedly subjected to silica gel and ODS column chromatography as well as preparative thin layer chromatography (PTLC) on silica gel $\mathrm{GF}_{254}$ to afford a compounds $\mathbf{1}$ and $\mathbf{2}$ (Figure 1).

Compound 1 was obtained as a white amorphous solid. The molecular formula was determined to be $\mathrm{C}_{15} \mathrm{H}_{26} \mathrm{O}_{2}$ on the basis of HRTOFMS spectrum showed $[\mathrm{M}+\mathrm{H}]^{+} \mathrm{m} / \mathrm{z}$ 237.1907 (calcd. $m / z$ 237.1855) and NMR spectral data (Table 1), thus requiring three degree of unsaturations. The IR spectra of compound 2 showed absorption peaks due to of hydroxyl group $\left(3420 \mathrm{~cm}^{-1}\right)$, aliphatics (2970 and $2870 \mathrm{~cm}^{-1}$ ), isolated double bond $\left(1580 \mathrm{~cm}^{-1}\right)$ and ether group $\left(1168 \mathrm{~cm}^{-1}\right)$. 

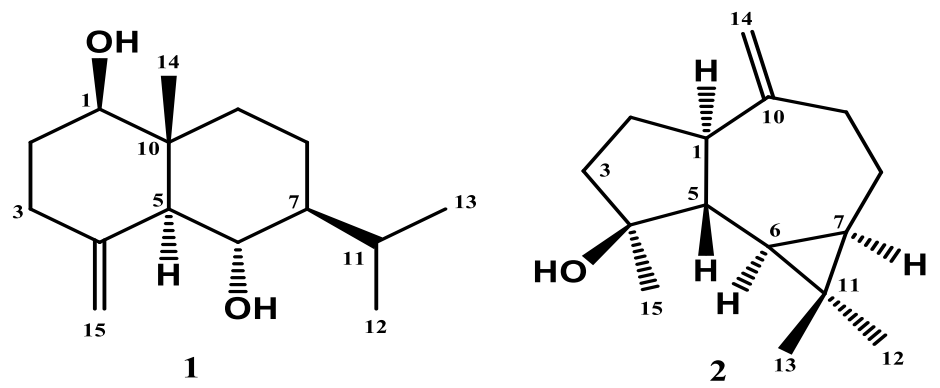

Figure 1. Chemical Structures of Compounds 1 and 2
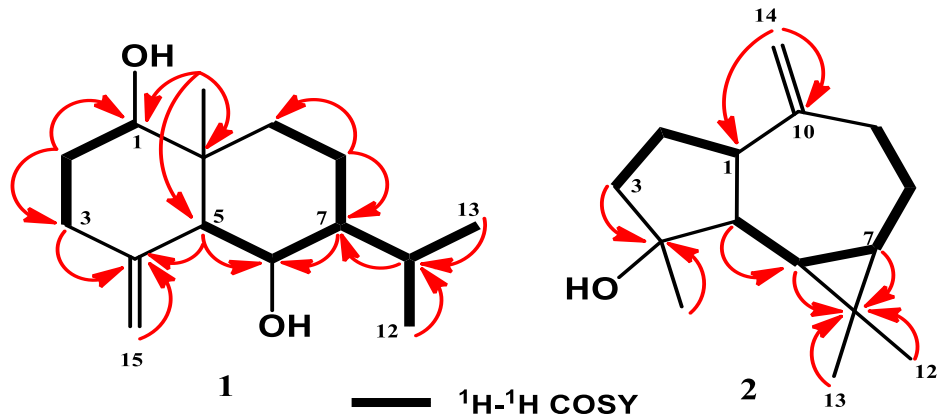

${ }^{1} \mathrm{H}-{ }^{1} \mathrm{H}$ COSY

HMBC

Figure 2. Selected ${ }^{1} \mathrm{H}-{ }^{1} \mathrm{H}$ COSY and HMBC Correlations for Compounds $\mathbf{1}$ and 2.

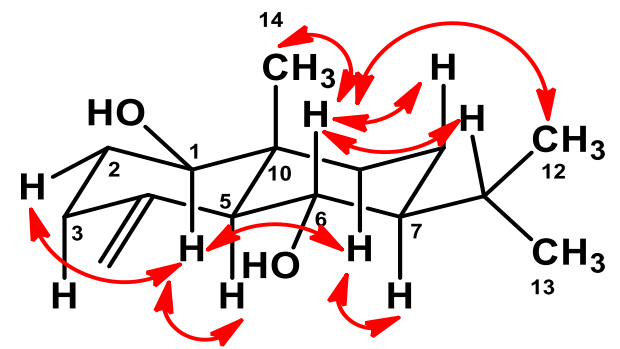

Figure 3. Selected NOE correlations for 1

${ }^{1} \mathrm{H}-\mathrm{NMR}$ spectrum showed a singlet methyl signal at $\delta_{\mathrm{H}} 0.70\left(3 \mathrm{H}, \mathrm{s}, \mathrm{CH}_{3}-14\right)$, two doublet methyl signals $\delta_{\mathrm{H}} 0.87(3 \mathrm{H}, \mathrm{d}, J=7.0$ $\left.\mathrm{Hz}, \mathrm{CH}_{3}-12\right)$ and $0.95\left(3 \mathrm{H}, \mathrm{d}, J=7.0 \mathrm{~Hz}, \mathrm{CH}_{3}-\right.$ 13) were assigned to an isopropyl group. Two oxygenated methine proton signals at $\delta_{\mathrm{H}} 3.42$ $(1 \mathrm{H}, \mathrm{dd}, J=4.8,11.6 \mathrm{~Hz}), \delta_{\mathrm{H}} 3.71(1 \mathrm{H}, \mathrm{m})$ were also observed in the ${ }^{1} \mathrm{H}-\mathrm{NMR}$ spectrum. In addition, the presence of a $\mathrm{sp}^{2}$ gemmethylene proton signals were observed at $\delta_{\mathrm{H}}$ $4.74(1 \mathrm{H}, \mathrm{d}, J=1.0 \mathrm{~Hz}), 5.02(1 \mathrm{H}, \mathrm{d}, J=1.0 \mathrm{~Hz})$ and other aliphatic signals at upfield regions also were oberved in the ${ }^{1} \mathrm{H}-\mathrm{NMR}$ spectrum. The ${ }^{13} \mathrm{C}-\mathrm{NMR}$ spectrum showed fifteen carbon signals, which were classified by their chemical shifts and DEPT spectra as one tertiary methyl, two secondary methyls, two oxygenated $\mathrm{sp}^{3}$ methines, one $\mathrm{sp}^{2}$ methylenes, one $\mathrm{sp}^{2}$ quaternary, four $\mathrm{sp}^{3}$ methylenes, three $\mathrm{sp}^{3}$ methines and one $\mathrm{sp}^{3}$ quaternary carbons. This functionalities accounted for one out of the total three degrees of unsaturation. The remaining of two degrees of unsaturation were consistent with eudesmen-type sesquiterpenoid skeleton (Kitajima, Suzuki, Satoh, \& Watanabe, 2002).

In order to clarify the position of functional group in compound $1,{ }^{1} \mathrm{H}-{ }^{1} \mathrm{H}$ COSY and $\mathrm{HMBC}$ experiments were carried out and the results were shown in Figure 2. The ${ }^{1} \mathrm{H}-{ }^{1} \mathrm{H}$ COSY spectrum of $\mathbf{1}$ showed correlations in $\mathrm{C}_{1}-\mathrm{C}_{2}-\mathrm{C}_{3}, \quad \mathrm{C}_{5}-\mathrm{C}_{6}-\mathrm{C}_{7}-\mathrm{C}_{8}-\mathrm{C}_{9}, \quad$ and $\mathrm{C}_{11}-\mathrm{C}_{7}$, supporting the presence of eudesmene-type sesquiterpenoid skeleton in compound 1. A tertiery methyl signal at $\delta_{\mathrm{H}} 0.73$ was correlated to $\mathrm{C}-10\left(\delta_{\mathrm{C}} 41.7\right), \mathrm{C}-9\left(\delta_{\mathrm{C}} 36.3\right)$ and $\mathrm{C}-1\left(\delta_{\mathrm{C}}\right.$ 79.0), whereas methylene protons at $\delta_{\mathrm{H}} 1.86$ was correlated to $\mathrm{C}-1\left(\delta_{\mathrm{C}} 79.0\right)$ and $\mathrm{C}-3\left(\delta_{\mathrm{C}}\right.$ 35.1 ), indicating that position of secondary hydroxy and tertiary methyl were located at C1 and $\mathrm{C}-10$, respectively. An oxygenated 
proton at $\delta_{\mathrm{H}} 3.71(\mathrm{H}-6)$ was mutually coupled to $\mathrm{sp}^{3}$ methine protons at $\delta_{\mathrm{H}} 1.75(\mathrm{H}-5)$ and $1.31(\mathrm{H}-7)$, whereas those $\mathrm{sp}^{3}$ methine protons were correlated to oxygenated methine carbon at $\delta_{\mathrm{C}} 67.0$ (C-6), suggesting that another secondary hydroxyl group was located at C-6. A deshielded methylene protons at $\delta_{\mathrm{H}} 4.74$ $(1 \mathrm{H}, \mathrm{d}, J=1.0 \mathrm{~Hz})$ and $5.02(1 \mathrm{H}, \mathrm{d}, J=1.0 \mathrm{~Hz})$ are mutually coupled and were correlated to $\mathrm{C}$ $4\left(\delta_{\mathrm{C}} 146.2\right)$, whereas methine proton at $\delta_{\mathrm{H}}$ 1.75 (H-5) was correlated to C-4 ( $\left.\delta_{\mathrm{C}} 146.2\right)$, indicating that an olefenic terminal moiety was located at C-4. Two secondary methyls at $\delta_{\mathrm{H}}$ $0.87\left(3 \mathrm{H}, \mathrm{d}, J=7.0 \mathrm{~Hz}, \mathrm{CH}_{3}-12\right)$ and $0.95(3 \mathrm{H}$, $\left.\mathrm{d}, J=7.0 \mathrm{~Hz}, \mathrm{CH}_{3}-13\right)$, were correlated to $\mathrm{C}-11$ $\left(\delta_{\mathrm{C}} 26.0\right)$, whereas methine proton at $\delta_{\mathrm{H}} 2.24$ (H-11) was correlated to C-7 $\left(\delta_{\mathrm{C}} 49.3\right)$ and C$11\left(\delta_{\mathrm{C}} 26.0\right)$ indicated that an isopropyl group was located at C-7.

The relative stereochemistry of compound $\mathbf{1}$ was supported by NOESY spectrum (Figure 3) and based on coupling contant $\left({ }^{3} J\right)$ of vicinal proton. NOE correlation between $\mathrm{H}-2, \mathrm{H}-1$ and $\mathrm{H}-5$, supporting that 1$\mathrm{OH}$ was $\beta$-configuration. NOE correlation between $\mathrm{CH}_{3}-14$ and $\mathrm{H}-6$, supporting that 6$\mathrm{OH}$ was $\alpha$-configuration. An isopropyl moiety was determined as $\beta$-oriented based on NOE correlation between $\mathrm{H}-7$ and $\mathrm{H}-5$. A detailed comparison of compound 1 to those of 4(15)eudesmen-1 $\beta, 6 \alpha$-diol was isolated from Caragana intermedia (Sun, Chen, Zhang, \& $\mathrm{Hu}, 2004)$, revealed that both compounds were very similar, consequently compound $\mathbf{1}$ was identified as $4(15)$-eudesmen-1 $\beta, 6 \alpha$-diol. That compound was isolated also from Torilis japonica (Apiaceae) (Kitajima et al., 2002), Helianthus microchephalus (Asteraceae) (Gutierrez \&Herz, 1988), Ambrosia elatior (Asteraceae) (Ohmoto, Ikeda, Nomura, Shimizu, \& Saito, 1987) and Croton arboreous (Euphorbiaceae) (Aguilar-Guadarrama \& Rios, 2004), but 4(15)-eudesmen-1 $\beta$, 6 $\alpha$-diol (1) was isolated from A. minahassae for the first time.

Compound 2 was obtained as a colorless oil. The molecular formula was determined to be $\mathrm{C}_{15} \mathrm{H}_{24} \mathrm{O}$ on the basis of HR-TOFMS spectrum showed $[\mathrm{M}+\mathrm{H}]^{+} \mathrm{m} / \mathrm{z} 220.3505$ (calcd. $\mathrm{m} / \mathrm{z}$ 220.3512) and NMR spectral data (Table 1), thus requiring four degrees of unsaturation. The IR spectra showed absorption peaks at $3450 \mathrm{~cm}^{-1}(\mathrm{OH}), 2990$ and $2860 \quad(\mathrm{C}-\mathrm{H}$ aliphatics), $1585 \mathrm{~cm}^{-1}(\mathrm{C}=\mathrm{C}$ olefinic $)$ and 1120 $\mathrm{cm}^{-1}$ (C-O ether). The ${ }^{1} \mathrm{H}-\mathrm{NMR}$ spectrum of compound 2 showed the presence of three tertiary methyl signals at $\delta_{\mathrm{H}} 1.02\left(3 \mathrm{H}, \mathrm{s}, \mathrm{CH}_{3^{-}}\right.$ 12), $1.27\left(3 \mathrm{H}, \mathrm{s}, \mathrm{CH}_{3}-15\right)$, and $1.04(3 \mathrm{H}, \mathrm{s}$, $\mathrm{CH}_{3}-13$ ), indicated the characteristics of aromadendran-type sesquiterpenoid (Phongmaykin, Kumamoto, Ishikawa, Suttisri, Saifah, 2008). The presence of an olefinic methylene signal resonances at $\delta_{\mathrm{H}} 4.65(1 \mathrm{H}, \mathrm{d}$, $J=2.1 \mathrm{~Hz}, \mathrm{H}-14 \mathrm{a})$ and $4.67(1 \mathrm{H}, \mathrm{d}, J=2.1 \mathrm{~Hz}$, $\mathrm{H}-14 \mathrm{~b}$ ), was also observed in the ${ }^{1} \mathrm{H}$ NMR spectrum.

The ${ }^{13} \mathrm{C}$-NMR spectrum of compound $\mathbf{2}$ in combination with DEPT experiments displayed the presence of fifteen carbon signals comprising of three tertiary methyl, one $\mathrm{sp}^{2}$ methylene, one $\mathrm{sp}^{2}$ quaternary carbon, one oxygenated $\mathrm{sp}^{3}$ quaternary carbon, four $\mathrm{sp}^{3}$ methylene, four $\mathrm{sp}^{3}$ methines, and one $\mathrm{sp}^{3}$ quaternary carbon. This functionalities accounted for one out of the total four degrees of unsaturation. The remaining of three degrees of unsaturation were consistent with tricyclic aromadendran-type sesquiterpenoid (Phongmaykin, Kumamoto, Ishikawa, Suttisri, Saifah, 2008).

The chemical structure of $\mathbf{1}$ was deduced from the ${ }^{1} \mathrm{H}-{ }^{1} \mathrm{H}$ COSY and HMBC spectra (Figure 2). ${ }^{1} \mathrm{H}-{ }^{1} \mathrm{H}-\mathrm{COSY}$ corelations at $\mathrm{C}_{3}-\mathrm{C}_{2}-$ $\mathrm{C}_{1}-\mathrm{C}_{5}-\mathrm{C}_{6}-\mathrm{C}_{7}-\mathrm{C}_{8}-\mathrm{C}_{9}$, supporting the presence of tricylic aromadendran-type sesquiterpenoid in compound 1. A sp ${ }^{2}$ methylene proton at $\delta_{\mathrm{H}} 4.65$ $(\mathrm{H}-14 \mathrm{a})$ and $4.67(\mathrm{H}-14 \mathrm{~b})$ were correlated to $\mathrm{C}-10\left(\delta_{\mathrm{C}} 153.5\right)$ and $\mathrm{C}-1\left(\delta_{\mathrm{C}} 53.5\right)$, whereas methylene proton at $\delta_{\mathrm{C}} 2.41(\mathrm{H}-9 \mathrm{a})$ and 2.04 $(\mathrm{H}-9 \mathrm{~b})$ were correlated to $\mathrm{C}-10\left(\delta_{\mathrm{C}} 153.5\right)$, indicating that olefinic moiety was located at C-10. A tertiary methyl at $\delta_{\mathrm{H}} 1.27\left(\mathrm{CH}_{3}-4\right)$ and methine proton at $\delta_{\mathrm{H}} 1.30(\mathrm{H}-5)$ were correlated to oxygenated carbon at $\delta_{\mathrm{C}} 81.1$ (C$4)$, whereas methylene proton at $\delta_{\mathrm{H}} 1.75(\mathrm{H}-3 \mathrm{a})$ and $1.55(\mathrm{H}-3 b)$ were correlated also to oxygenated carbon at $\delta_{\mathrm{C}} 81.1$ (C-4), indicating that tertiary hydroxyl group was located at C-4. A gem-dimethyl protons at $\delta_{\mathrm{H}} 1.02\left(\mathrm{CH}_{3}-12\right)$ and $1.04\left(\mathrm{CH}_{3}-13\right)$ were correlated to quaternary carbon at $\delta_{\mathrm{C}} 20.4(\mathrm{C}-11)$, whereas methine protons at $\delta_{\mathrm{H}} 0.45(\mathrm{H}-6)$ and $0.70(\mathrm{H}-$ 7) were correlated also to quaternary carbon at $\delta_{\mathrm{C}} 20.4$ (C-11), indicating that a gem-dimethyl attached at cyclopropane ring at C-11. A detailed comparison of NMR spectra of compound 2 to those of tricylic aromadendrantype sesquiterpenoid, spatulenol (Phongmaykin, Kumamoto, Ishikawa, Suttisri) 
Table 1. NMR data for Compounds 1 and $2\left(\mathrm{CDCl}_{3}, 500 \mathrm{MHz}\right.$ for ${ }^{1} \mathrm{H}$ and 125 for $\left.{ }^{13} \mathrm{C}\right)$

\begin{tabular}{cll|ll}
\hline Position & \multicolumn{2}{c|}{$\mathbf{1}$} & \multicolumn{2}{c}{$\mathbf{2}$} \\
\cline { 2 - 5 } Carbon & \multicolumn{1}{c}{$\delta_{\mathrm{H}}[(\Sigma \mathrm{H}$, mult., $J(\mathrm{~Hz})]$} & $\delta_{\mathrm{C}}($ mult. $)$ & \multicolumn{1}{c}{$\delta_{\mathrm{H}}[(\Sigma \mathrm{H}, \mathrm{mult} ., J(\mathrm{~Hz})]$} & $\delta_{\mathrm{C}}(\mathrm{mult})$. \\
\hline 1 & $3.42(1 \mathrm{H}, \mathrm{dd}, 4.8,11.6)$ & $79.0(\mathrm{~d})$ & $1.30(1 \mathrm{H}, \mathrm{dd}, 5.6,7.0)$ & $53.5(\mathrm{~d})$ \\
2 & $1.55(1 \mathrm{H}, \mathrm{m})$ & $31.9(\mathrm{t})$ & $1.62(1 \mathrm{H}, \mathrm{dd}, 7.0,9.5)$ & $26.7(\mathrm{t})$ \\
& $1.86(1 \mathrm{H}, \mathrm{m})$ & & $1.89(1 \mathrm{H}, \mathrm{m})$ & \\
3 & $2.05(1 \mathrm{H}, \mathrm{td}, 8.1,13.3)$ & $35.1(\mathrm{t})$ & $1.55(1 \mathrm{H}, \mathrm{m})$ & $41.7(\mathrm{t})$ \\
& $2.33(1 \mathrm{H}, \mathrm{ddd}, 2.2,5.0,13.1)$ & & $1.75(1 \mathrm{H}, \mathrm{m})$ & \\
4 & - & $146.2(\mathrm{~s})$ & - & $80.0(\mathrm{~s})$ \\
5 & $1.75(1 \mathrm{H}, \mathrm{d}, 9.8)$ & $55.9(\mathrm{~d})$ & $1.30(1 \mathrm{H}, \mathrm{t}, 9.0)$ & $54.5(\mathrm{~d})$ \\
6 & $3.71(1 \mathrm{H}, \mathrm{t}, 9.8)$ & $67.0(\mathrm{~d})$ & $0.45(1 \mathrm{H}, \mathrm{dd}, 9.0,10.8)$ & $29.9(\mathrm{~d})$ \\
7 & $1.31(1 \mathrm{H}, \mathrm{m})$ & $49.3(\mathrm{~d})$ & $0.70(1 \mathrm{H}, \mathrm{dd}, 6.2,8.9)$ & $27.5(\mathrm{~d})$ \\
8 & $1.20(1 \mathrm{H}, \mathrm{m})$ & $18.2(\mathrm{t})$ & $1.96(1 \mathrm{H}, \mathrm{d}, 6.2)$ & $24.8(\mathrm{t})$ \\
& $1.54(1 \mathrm{H}, \mathrm{m})$ & & $2.02(1 \mathrm{H}, \mathrm{m})$ & \\
9 & $1.19(1 \mathrm{H}, \mathrm{m})$ & $36.3(\mathrm{t})$ & $2.04(1 \mathrm{H}, \mathrm{dd}, 6.0,13.8)$ & $38.9(\mathrm{t})$ \\
& $1.92(1 \mathrm{H}, \mathrm{m})$ & & $2.41(1 \mathrm{H}, \mathrm{dd}, 6.0,13.9)$ & \\
10 & - & $41.7(\mathrm{~s})$ & - & $153.5(\mathrm{~s})$ \\
11 & $2.24(1 \mathrm{H}, \mathrm{m})$ & $26.0(\mathrm{~d})$ & - & $20.4(\mathrm{~s})$ \\
12 & $0.87(3 \mathrm{H}, \mathrm{d}, 7.0)$ & $16.2(\mathrm{q})$ & $1.02(3 \mathrm{H}, \mathrm{s})$ & $16.4(\mathrm{q})$ \\
13 & $0.95(3 \mathrm{H}, \mathrm{d}, 7.0)$ & $21.1(\mathrm{q})$ & $1.04(3 \mathrm{H}, \mathrm{s})$ & $28.7(\mathrm{q})$ \\
14 & $0.70(3 \mathrm{H}, \mathrm{s})$ & $11.6(\mathrm{q})$ & $4.65(1 \mathrm{H}, \mathrm{d}, 2.1)$ & $106.4(\mathrm{t})$ \\
& & & $4.67(1 \mathrm{H}, \mathrm{d}, 2.1)$ & \\
15 & $4.74(1 \mathrm{H}, \mathrm{d}, 1.0)$ & $107.8(\mathrm{t})$ & $1.27(3 \mathrm{H}, \mathrm{s})$ & $26.2(\mathrm{q})$ \\
& $5.02(1 \mathrm{H}, \mathrm{d}, 1.0)$ & & & \\
\hline
\end{tabular}

Saifah, 2008), revealed that both compounds were very similar, consequently compound $\mathbf{2}$ was identified as a spatulenol. The relative stereochemistry was determined as a spatulenol based on the similirity of vicinal coupling constant $\left({ }^{3} J\right)$ values in the ${ }^{1} \mathrm{H}$ NMR spectrum, such as ${ }^{3} J$ between $\mathrm{H}-1$ and $\mathrm{H}-2$ (7.0 $\mathrm{Hz}), \mathrm{H}-5$ and $\mathrm{H}-6(9.0 \mathrm{~Hz})$ as well as $\mathrm{H}-6$ and $\mathrm{H}-7 \quad(6.2 \mathrm{~Hz})$ and others similarity. Consequently compound $\mathbf{1}$ was identified as a spatulenol. The compound was isolated also from Vernoniamollissima (Asteraceae) (Krebs, Rakotoarimaya, \& Harbernahl, 1990) and Homalomena aromatica (Araceae) (Policegoudra et al., 2012), but was isolated from A. minahassae for the first time.

\section{CONCLUSIONS}

Eudesmaene-type sesquiterpenoid, 4(15)eudesmen-1 $\beta, 6 \alpha$-diol (1) and aromadendrantype sesquiterpenoid compounds, spathulenol (2) have been isolated from the stembark of $A$. minahassae. Both compounds were isolated from this plant for the first time and indicated the ability of Aglaia species to produce a sesquiterpenoid compounds. The discovery of two sesquiterpene compounds from the stembark of $A$. minahassaealso reinforces previous phytochemical studies of the occurance of sesquiterpenoid in the Aglaia genus.

\section{ACKNOWLEDGEMENTS}

This research was financially supported by Directorate General of Higher Education, Ministry of Research, Technology and Higher Education, Indonesia (Postgraduate Grant, 2016-2018 by Unang Supratman).

\section{REFERENCES}

Aguilar-Guadarrama, A.B. \& M.Y. Rios. (2004). Three new sesquiterpenes from Croton arboreous. Journal of Natural Products. 67(5), 914-917.

Awang, K., Loong, X.M., Leong, K.H., Supratman, U., Litaudon, M., Mukhtar, M.R., \&Mohamad, K. (2012). Triterpenes and steroids from the leaves of Aglaia exima (Meliaceae). Fitoterapia, 83, 1391-1395. 
Cai, X., Wang, Y., Zhao, P., Li, Y., \&Luo, X. (2010). Dolabellane diterpenoids from Aglaia odorata. Phytochemistry, 71, 1020-1024.

Farabi, K., Harneti, D., Nurlelasari., Maharani, R., Hidayat, A.C., Awang, K., Supratman, U., \& Shiono, Y. (2017). New cytotoxic protolimonoids from the stem bark of Aglaia argentea (Meliaceae). Phytochemistry Letters, 21, 211-215.

Feraz, R., Cardozo, G., da Silva T., Fontes, J., Prata, A. (2013). Antitumour properties of the leaf essential oil of Xylopia frutescens. Food Chemistry 141(1):196200.

Gutierrez, A.B. \& W. Herz. (1988). Guaianolides and Other Constituents of Helianthus microcephalus. Phytochemistry. 27(7), 2225-2228.

Harneti, D., Supriadin, A., Ulfah, M., Safari, A., Supratman, U., Awang, K., \& Hayashi, H. (2014). Cytotoxic constituents from the bark of Aglaia eximia (Meliaceae). Phytochemistry Letters 8, 28-31.

Harneti, D., Tjokronegoro, R., Safari, A., Supratman, U.,Loong, X.M., Mukhtar, M.R., Mohamad, K., Awang, K.,\&Hayashi, H. (2012). Cytotoxic triterpenoids from the bark of Aglaiasmithii. Phytochemistry Letters,5, 496-499.

Heyne, K., 1982. "The Useful Indonesian Plants", Research and Development Agency, Ministry of Forestry, Jakarta, Indonesia. 1029-1031.

Hidayat, A,T., Farabi, K., Harneti, D., Nurlelasari, Maharani, R., Mayanti, T., Supratman, U \&Shiono, Y. (2017a). A Cytotoxic Rocaglate Compound from The Stembark of Aglaia argentea (Meliaceae). Molekul, 12(2), 146-152.

Hidayat, A,T., Farabi, K., Harneti, D., Maharani, R., Darwati, Nurlelasari, Mayanti, T., Arlette Suzy Setiawan, A.S., Supratman, U \& Shiono, Y. (2017b). Cytotoxicity and Structure Activity Relationship of DammaraneTypeTriterpenoids from the Bark of Aglaia elliptica against P-388 Murine Leukemia Cells, Natural Product Sciences. 23(4): 291-298.

Ishnava, K., Chauhan, J., Barad, M. (2013). Anticariogenic and phytochemical evaluation of Eucalyptus globulus. Saudi Journal of Biological Sciences. 20(1), 110.

Jeena, K., Liju, V., Kuttan, R. (2013). Antioxidant, anti-inflammatory and antinociceptive activities of essential oil from ginger. Indian Journal of Physiology Pharmacology 57(1):51-62.

Joycharat, N., Plodpai, P., Panthong, K., Yingyongnarongkul, B., \&Voravuthikunchai, S.P. (2010). Terpenoid constituents and antifungal activity of Aglaia forbesii seed against phytopathogens. Canadian Journal of Chemistry,88, 937-944.

Kitajima, J., Suzuki, N.,. Satoh, M \& Watanabe, M.(2002). Sesquiterpenoids of Torilis japonica Fruit. Phytochemistry. 59, 811-815.

Krebs, H,C., Rakotoarimanya, J,V \& Harbermehl, G,G. (1990). Isolation of spatulenol and (-)-caryophyllene oxide from Vernoniamollissima don and ${ }^{1} \mathrm{H}$ and ${ }^{13} \mathrm{C}$ reassignment by twodimensional NMR spectroscopy. Magnetic Resonance in Chemistry, 28, 124-128.

Leong, K.H., Looi, C.Y., Loong, X,W., Cheah, F,K., Supratman, U., Litaudon, M., Mohd Rais Mustafa, M,R., Awang, K. (2016). Cycloart-24-ene-26-ol-3-one, a New Cycloartane Isolated from Leaves of Aglaia exima Triggers Tumour Necrosis Factor- Receptor 1-Mediated Caspase-Dependent Apoptosis in Colon Cancer Cell Line. PLOS ONE, 4, 1-17.

Liu, S., Liu, S.B., Zuo, W., Guo, Z., Mei, W., $\&$ Dai, H. (2014). New sesquiterpenoids from Aglaia odorata var. microphyllina and their cytotoxic activity. Fitoterapia, 92, 93-99.

Nugroho, B.W., Edrada, R.A., Wray, V., Witte L., Bringmann, G., Gehling, M., \&Proksch, P. (1999). An insectisidal rocaglamida derivates and related compounds from Aglaia odorata (Meliaceae). Phytochemistry, 51, 367376.

Ohmoto, T., K. Ikeda, S. Nomura, M. Shimizu \& S. Saito. (1987). Studies on the Sesquiterpenes from Ambrosia elatior Linne. Chemistry Pharmaceutical Bulletin. 35(6), 2272-2279.

Ornano, L., Venditti, A., Ballero, M., Sanna, C., Quassinti, L. (2013). 
Chemopreventive and antioxidant activity of the chamazulene-rich essential oil obtained from Artemisia arborescens $\mathrm{L}$. growing on the Isle of $\mathrm{La}$ Maddalena, Sardinia, Italy. Chemistry and Biodiversity 10(8):1464-74.

Pan, L., L.B.S. Kardono, S. Riswan, H. Chai, E.J. Carcache de Blanco, C.M. Pannell, D.D. Soejarto, T.G. McCloud, D.J. Newman \& A.D. Kinghorn, (2010) Isolation and characterization of minor analogues of silvestrol and other constituents from a large-scale recollection of Aglaia foveolatia. Journal of Natural Products. 73(4), 1873-1878.

Park, K., Nam, D., Hun, H., Le, S., Jang, H. (2011). $\beta$-Caryophyllene oxide inhibits growth and induces apoptosis through the suppression of PI3K/AKT/mTOR/S6K1 pathways and ROS-mediated MAPKs activation. Cancer Letters 312(2):178-88.

Phongmaykin, J., Kumamoto, T., Ishikawa, T., Suttisri, R., Saifah, E., (2008). A new sesquiterpene and other terpenoid constituents of Chisocheton penduliflorus. Archive of Pharmacal Research. 31, 21-27.

Policegoudra,R.S., Goswami, S., Aradhya, S.M., Chatterjee, S.M., Datta, S., Sivaswam, S,R., Chattopadhyay, R., (2012). Bioactive constituents of Homalomena aromaticaessential oil and its antifungal activity against dermatophytes and yeasts. Journal de Mycologie Médicale, 22(1), 83-87.

Sianturi, J., Harneti, D., Darwati, Mayanti, T., Supratman, U., \&Awang, K. (2016). A New(-)-5',6-dimethoxyisolariciresinol(3", $4^{\prime \prime}$-dimethoxy)-3 $\alpha-O-\beta$ glucopyranoside from the bark of Aglaia eximia (Meliaceae). Natural Products Research, 30, 2204-2208.

Su, B., Chai, H., Mi, Q., Riswan, S., Kardono, L.B.S., Afriastini, J. J., Santarsiero, B.
D., Mesecar, A. D., Fransworth, N. R., Cordell, G. A., Swanson, S. M.,\&Kinghorn, D. (2006). Activityguided isolation of cytotoxic constituents from the bark of Aglaiacrassinervia collected in Indonesia. Bioorganic and Medicinal Chemistry, 14, 960-972.

Sun, Z., B. Chen, S. Zhang, \& C. Hu. (2004). Four New Eudesmanes from Caragana intermedia and Their Biological Activities. Journal of Natural Products. 4(15), 1975-1979.

Waterman P. (1993). The chemistry of volatile oils. In Hay R, Waterman P (eds.), Volatile Oil Crops: Their Biology, Biochemistry and Production. Essex, UK: Longman Scientific and Technical, 47-61.

Wood, D.L., Silverstain, R.M., \&Nakajima, M. (1970). Control of Insects Behavior by Natural Product. Academic Press. New York.

Xie, B.J., Yang, S.P, Chen, H.D., \&Yue. J.M. (2007). Triterpenoids from Aglaia duperreana. Journal of Natural Products, 70, 1532-1535.

Yodsaoue, O., Sonprasit, J., Karalai, C., Ponglimanont, C., Tewtrakul, S., \&Chantrapromma, S. (2012). Diterpenoids and triterpenoids with potential anti-inflammatory activity from the leaves of Aglaia odorata. Phytochemistry, 76, 83-91.

Zhang, F., Wang, J.S., Gu, Y.C., \&Kong, L.Y. (2010). Triterpenoids from Aglaia abbreviata and their cytotoxic activities. Journal of Natural Products, 73, 20422046.

Zhang, F., Zhu, Y., Li, Q., \& Cen, J.. (2016). Four New Pregnane Steroids from Aglaia abbreviate and Their Cytotoxic Activities. Helvetica Chimica Acta. 99, 73-77. 